\title{
Triple Helix or Quadruple Helix: Which Model of Innovation to Choose for Empirical Studies?
}

\author{
Yuzhuo Cai ${ }^{1}$ (D) Annina Lattu ${ }^{1,2}$ (D)
}

Accepted: 9 September 2021 / Published online: 28 October 2021

(C) The Author(s) 2021

\begin{abstract}
While the Triple Helix and Quadruple Helix models are popular in innovation studies, the relations between them have not been addressed extensively in the literature. There are diverse interpretations of helix models in empirical studies that apply them, but these sometimes deviate from the original theses of the models. Such a situation can confuse newcomers to the field in terms of which helix model to apply in their empirical research. We discern that the cause of this research challenge is a lack of systematic comparison of the two models. To bridge the research gap, this paper compares the models from the perspectives of how they were introduced and discussed in the literature and improved and how useful they are in addressing the innovation processes in contemporary society. Our major findings are as follows: First, reviewing the extant literature applying the two helix models for identifying research gaps, we discover that these studies were influenced by three views on the relations between the two models that were located on a continuum between two extreme ends-namely, isolation versus integration of the two models. Second, we provide a systematic comparison of both the advantages and weaknesses of the two models, and this may help researchers choose suitable helix models as conceptual/analytical tools in their empirical innovation studies. Third, our comparison of the two models shows that they are largely supplementary to each other when analysing innovation processes in contemporary society, providing a ground for potential synergy building between the two helix models.
\end{abstract}

Yuzhuo Cai

yuzhuo.cai@tuni.fi

Annina Lattu

annina.lattu@tuni.fi

1 Faculty of Management and Business, Tampere University, P.O.Box 200, 33014 Tampere, Finland

2 Graduate School of Education, Peking University, 100871 Beijing, China 
Keywords Triple helix - Quadruple helix · Quintuple helix $\cdot$ Helix model of innovation · University-industry-government · Civil society · Innovation ecosystem · Sustainable development

\section{Introduction}

Innovation studies are teeming with new concepts that attempt to capture the new features of contemporary society. Among the most popular conceptual frameworks used in innovation studies, the Triple Helix and Quadruple Helix models of innovation are two seemingly competing concepts that have been broadly applied in empirical investigations in innovation studies. The Triple Helix model was originally proposed by Etzkowitz and Leydesdorff (1995) to explain the dynamic interactions between academia, industry and government for fostering entrepreneurship, innovation and economic growth in a knowledge-based economy (Etzkowitz and Leydesdorff 2000). Since then, the Triple Helix model has quickly become a popular concept in innovation studies. At the same time, its explanatory power has been challenged by some sceptics (see examples in Cai and Etzkowitz 2020), particularly after the development of the Quadruple Helix model, which incorporates public or civil society as the fourth helix, by Carayannis and Campbell (2009).

Carayannis and Campbell (2010, 2013) also proposed the Quintuple Helix by adding a fifth helix - the natural environments of society. The Quintuple Helix addresses the socio-ecological transition of society and economy in the twenty-first century, bringing an ecologically sensitive perspective to the discussion of innovation and knowledge production (Carayannis and Campbell 2010, 2013). However, it is less popular in empirical studies compared with the Quadruple Helix model, probably because 'the connection of the environmental helix with the other four helices is a challenge' (König et al. 2020: 8) in the conceptualisation of the Quintuple Helix. In this paper, we exclude the Quintuple Helix from our focus because it largely shares the theoretical rationale of the Quadruple Helix model (Carayannis and Campbell 2021).

To Carayannis and Campbell, the development of the Quadruple Helix and Quintuple Helix models was a response to the changing nature of the knowledge society. (See more about the characteristics of contemporary society in the section: Advantages and Disadvantages of the Triple Helix and Quadruple Helix Models). As Campbell (2019: 59) explained, 'the Triple Helix represents a basic core model of innovation for the "knowledge economy," while the Quadruple Helix describes the "knowledge society" and "knowledge democracy," whereas the Quintuple Helix also refers to "social ecology, society-nature interactions, [and] socioecological transition"". This is connected with an emerging perception: With growing public awareness of socially responsible innovation, as well as the role of civil society in science and technology development in governmental policies, people tend to find the Quadruple Helix model more timely and suitable for addressing new features of the society (Miller et al. 2018; De Oliveira Monteiro and Carayannis 2017).

The initiators of the Triple Helix model-Leydesdorff and Etzkowitz-were also keen on the change in society and its implications for the Triple Helix model. In 
2003, they wrote an article titled "Can "the public" be considered as a fourth helix in university-industry-government relations?' (Leydesdorff and Etzkowitz 2003). In it, they claimed that it is not necessary to transform the Triple Helix into a Quadruple Helix because civil society is not an institutional sphere on the same level as a university, industry or government; rather, the Triple Helix has most efficaciously evolved in an overarching societal framework guaranteeing freedom of speech and organisation-formation initiative. Instead of being ignored, civil society is considered too important to be a parallel helix to industry, university and government; it is seen as a key enabling condition of triple helix interactions (Etzkowitz 2008; Etzkowitz and Zhou 2017).

As noted by Leydesdorff (2012), defending the Triple Helix model does not mean being limited to the three helices for the explanation of complex developments. He suggested that whether more than three helices are needed in the analysis depends on the empirical context and the availability of empirical data (Leydesdorff 2012). However, Leydesdorff and Etzkowitz (2003) expressed a warning: 'So long as one is not able to operationalize and show development in the relatively simple case of three dimensions, one should be cautious in generalizing beyond the TH [Triple Helix] model to an N-tuple of helices' (33). This reflects 'triadic interactions as an Occam's razor principle' (Cai and Etzkowitz 2020: 202) - a theoretical core of the Triple Helix model.

The debates on the two helix models often confuse newcomers to the field as to which helix model should be applied in their empirical research. Partially to respond to the situation, the originators of both the Triple Helix model and Quadruple Helix model, sometimes together with their co-authors, tried to clarify both concepts and the relations between them. For instance, Carayannis and Campbell (2021) articulated the evolution of Quadruple and Quintuple Helix innovation systems by emphasising that the systems have emerged as a response to the transformation towards Society 5.0, which 'aims to put human beings at the centre of innovation, taking advantage of the impact of technology and the results of industry 4.0 with the deepening of technological integration in improving quality of life, social responsibility and sustainability' (15). The authors also highlighted the role of democratic regimes by stating that the evolution of knowledge and innovation depends on democracy and knowledge democracy, which is considered in the Quadruple and Quintuple Helix models (22). Meanwhile, they emphasised that the Quadruple and Quintuple Helix models are based on the Triple Helix model and fully conceptualise this model. In their article on Triple, Quadruple and Higher-Order Helices, Leydesdorff and Smith (2021) re-affirmed the importance of Simmel's triad concept that the differences between triads and larger cliques are insignificant. Therefore, Quadruple, Quintuple, or N-tuple Helices 'can-for analytical reasons-always be decomposed and recombined into interacting Triple Helices' (Leydesdorff and Smith 2021: 2). Partially as a response to recent studies on helix models of innovation that transcend the original triadic thesis, Cai and Etzkowitz (2020) highlighted the core theoretical rationales of the Triple Helix model in its original form and discussed the current development and future directions related to theorising the Triple Helix model.

Regardless of the claims by the initiators of the helix models, current research applying Triple/Quadruple Helix models has not clearly delineated the two models' 
differences and similarities (as discussed in the Literature Review section). In some studies, the authors even misunderstood the concepts. These efforts have been hampered by a lack of studies systematically comparing the two models, resulting in diverse interpretations of Triple or Quadruple Helix.

Our study aims to fill the gap outlined above by assessing the two models with appropriate comparative approaches. Specifically, we raise the following research questions:

(1) How were Triple Helix and Quadruple Helix models introduced and discussed in the literature?

(2) What pros and cons of the two models should researchers consider when deciding which models to apply in their empirical studies?

The rest of the paper is structured as follows. It starts with a literature review of studies applying Triple Helix and Quadruple Helix models to identify the research gap to be filled by this paper. In the next two sections, we answer the two research questions by using appropriate comparative lenses. Finally, we conclude with the major findings of our study, as well as its contribution to the literature.

\section{Literature Review: The Use of Triple Helix and Quadruple Helix Models in Innovation Studies}

In this section, we briefly review studies in which the authors compared Triple Helix and Quadruple Helix models when choosing one for their analyses. Based on our search on Web of Science (in all relevant fields of social sciences) on 28 December 2020, there were 305 articles that applied the Triple Helix model, 51 articles that applied the Quadruple Helix model and 37 articles that discussed both models. Our analysis of the literature is primarily based on these last 37 articles (but is not limited to them). Because of word limitations, only some example articles are presented here to illustrate our observations.

At the risk of oversimplification, it is evident that these studies are influenced by the three following views on the relations between the two helix models: (1) The Triple Helix model and Quadruple Helix model are competing concepts, (2) the move from Triple Helix to Quadruple Helix is an evolutionary process and (3) the Triple Helix and Quadruple Helix could supplement each other. The three perspectives can be placed on a continuum (Fig. 1).

\begin{tabular}{|c|c|c|c|c|}
\hline \multirow{2}{*}{$\begin{array}{l}\text { Triple Helix } \\
\text { and Quadruple } \\
\text { Helix models } \\
\text { are isolated }\end{array}$} & \\
\hline & $\begin{array}{l}\text { 1) The Triple Helix } \\
\text { model and Quadruple } \\
\text { Helix model are } \\
\text { competing concepts. }\end{array}$ & $\begin{array}{l}\text { 2) The move from } \\
\text { Triple Helix to } \\
\text { Quadruple Helix is an } \\
\text { evolutionary process. }\end{array}$ & $\begin{array}{l}\text { 3) ) The Triple Helix } \\
\text { and Quadruple Helix } \\
\text { could supplement each } \\
\text { other. }\end{array}$ & $\begin{array}{l}\text { and Quadruple } \\
\text { Helix models } \\
\text { are highly } \\
\text { integrated }\end{array}$ \\
\hline
\end{tabular}

Fig. 1 Three perspectives on the relations between Triple Helix and Quadruple Helix on a continuum 


\section{The Triple Helix Model and Quadruple Helix Model are Competing Concepts}

The choice of Triple Helix or Quadruple Helix models in some studies is associated with the authors' view of the two helix models as competing concepts. The proponents of the Quadruple Helix model criticise the Triple Helix for its exclusion of civil society from its analytical foci. For instance, in their study on communitydriven social innovation in a rural area, Nordberg et al. (2020) explained that they prefer the Quadruple Helix to the Triple Helix as a conceptual framework because the former, which adds civil society as a fourth helix, elucidates the variety of formal and informal ways of fostering social innovation. They emphasised that the Quadruple Helix model is especially useful for analysing the role of community in the innovation process. By the same logic, the Triple Helix model has been considered inadequate for analysing multiple sectoral collaborations for entrepreneurship in contemporary society (Mok and Jiang 2020).

The advocates of the Triple Helix model hold the position that the increasingly complex society can only be better understood when there is a clear understanding of the interactions of university, industry and government as the most important innovation players. As Zheng (2010) argued, compared with other approaches to innovation studies, including the Quadruple Helix, 'the Triple Helix model reduces the complexity of the dynamics at play in the innovation systems of the knowledge economy' (41). Such a reduction in complexity allows essential dynamics to be more clearly discerned. Similarly, Porto-Gomez et al. (2019) chose the Triple Helix model as an analytical tool for their study of innovation systems in Mexico by taking the 'systemness' advantage of the model. Thus, 'one can add as many players as one would like to reinforce the strength of the territory under analysis, let it be a country or a set [of] regions within a country' (Porto-Gomez et al. 2019: 2).

\section{The Move from Triple Helix to Quadruple Helix is an Evolutionary Process}

Studies taking this perspective share the perception that civil society is not addressed by the Triple Helix model. However, instead of seeing the Triple Helix as an outof-date concept, the authors value its conceptual elaboration on the interactions of university, industry and government and include civil society in their analytical framework. In other words, they see the transition from the Triple Helix model to the Quadruple Helix model as an evolutionary process. For instance, although the Quadruple Helix model was applied to study the role of non-profit organisations in innovation systems, Arranz et al. (2020) appreciated the theoretical rationales of Triple Helix interactions. Specifically, their analytical framework centred on how nonprofit organisations interact with the traditional helices of university, industry and government. By the same token, Marques et al. (2020) developed their Quadruple Helix analytical framework to investigate the influences of multiple stakeholders' motivations on technology transfer in the context of implementing a smart specialisation strategy in Europe, largely based on the theoretical and methodological powers of the Triple Helix model. 
Some sporadic studies have implied that the two helix models could supplement each other for synergy building, especially when addressing issues concerning sustainable innovations or innovation ecosystems. For instance, in a recent study on strengthening the science-policy-industry interface towards sustainability, Saviano et al. (2019) built a Triple Helix framework of sustainability by putting the interactions between science, policy and industry in the triple helix context of society, economy and environment. In so doing, they incorporate the insights of the Triple Helix, Quadruple Helix, Quintuple Helix and 'Triple Helix Twins' (Etzkowitz and Zhou 2006). A similar effort was made by Cai et al. (2019), who tried to construct a citizen-engaged Triple Helix model to analyse innovation ecosystems by integrating both Triple and Quadruple Helix models. These examples suggest the potential for synergy building between the two models.

\section{Research Gaps: Lack of Studies Comparing the Helix Models and the Misunderstandings of the Helix Models}

Our analysis of the literature (beyond the studies mentioned above as examples) reveals two research gaps. First, although the three perspectives on the relations between the Triple Helix and Quadruple Helix have been identified, none of them have been strongly supported by a solid comparison of the two models. Indeed, few studies have provided a systematic comparison of Triple Helix and Quadruple Helix models, although some are adjacent to this direction. For instance, in one recent publication, König et al. (2020) juxtapose the Triple, Quadruple and Quintuple Helix models with insightful discussions on each, but they do not provide a comparative analysis. A similar effort to describe Triple Helix and Quadruple Helix models was made by Miron and Gherasim (2018). The most comprehensive discussions on the Triple Helix and Quadruple Helix, to our knowledge, are provided by a special issue on the topic of "Beyond "Triple Helix" toward "Quadruple Helix" models in regional innovation systems: Implications for theory and practice' (McAdam and Debackere 2018). However, because of the nature of the publication format as a collection of works, there was no explicit and consistent comparative perspective applied in the discussions.

Second, the theoretical rationales of Triple Helix or Quadruple Helix models were often not fully comprehended when used for empirical studies. Many authors have only superficially cited the literature on the Triple Helix and Quadruple Helix topics. Particularly, we found three misunderstandings of the Triple Helix model, as delineated below.

The first misunderstanding is the perception that civil society is missing in the Triple Helix model, which serves as a major argument of many authors applying the Quadruple Helix model instead of the Triple Helix model (e.g., Nordberg et al. 2020; Arranz et al. 2020). However, this is a simplistic understanding of Triple Helix because civil society has been considered 'the launch pad for take-off 
[of] triple helix interactions' (Etzkowitz 2014: 19) or an institutional ground of the Triple Helix (Cai 2015). As Leydesdorff (2012: 30) stated, 'the [triple] helices represent specialization and codification in function systems which evolve from and within civil society'. Civil society is important for innovation because effective interaction between the three spirals is also contingent on broad social participation (Etzkowitz 2008). Nevertheless, the current Triple Helix model has not explicitly elucidated civil society in its analytical framework.

The second misunderstanding is equating the Triple Helix model to an innovation system. This is commonly seen in innovation studies (e.g., Arranz et al. 2020; Porto-Gomez et al. 2019). However, Etzkowitz and Zhou (2017) emphasised that the Triple Helix goes beyond innovation systems theory in that the innovation system has its theoretical root in general systems theory, whereas the Triple Helix model is grounded on Simmel's triadic interactions as an Occam's razor principle. As such, an innovation system is expected to evolve through selforganisation; in contrast, the Triple Helix model requires an organised acceleration process and innovation organisers. As Leydesdorff (2012: 25) posited, 'Using the Triple Helix model of university-industry-government relations, one can measure the extent to which innovation has become systemic instead of assuming the existence of national (or regional) systems of innovations on a prior grounds'.

Although the originators of the Triple Helix model try to avoid mixing the model with the concept of the innovation system, their elaboration on the differences between the Triple Helix model and the innovation system occurs on an abstract level (Cai 2020). This may explain why many scholars of innovation studies treat the Triple Helix model and innovation systems as exchangeable. However, it is worth noting that the development of Quadruple/Quintuple Helix models is intended to allow better interpretation of the ecosystems of innovation (Carayannis et al. 2018).

The third misunderstanding is that Triple Helix interactions are simply perceived as collaborative relations within tri-lateral networks (e.g., Mok and Jiang 2020; Farinha et al. 2016). Such an understanding does not help explain the following phenomenon: Whereas the collaborative relations between university, industry and government can be observed in most places in the world, the development of entrepreneurship and innovation differ between the regions. From the perspective of the Triple Helix model, only when the mechanism of 'taking the role of the other' exists in the tri-lateral networks can collaborative relations become an enabling condition fostering innovation and entrepreneurship (Etzkowitz 2008).

\section{Comparing the Triple Helix and Quadruple Helix in Their Original Forms}

When comparing the Triple Helix and Quadruple Helix in their original forms, we focus on the following three aspects: (1) How the models originated and were introduced to the literature; (2) what the major theoretical rationales of the models are and (3) how the models have been addressed by scholars. 


\section{Triple Helix}

\section{Origin of the Triple Helix Concept}

Etzkowitz (1993, 1994) and Leydesdorff (1994) simultaneously explored new perspectives of looking at the dynamics in regional innovation, with a particular emphasis on the role of academia and organised knowledge production, until they jointly developed the concept of the Triple Helix model of academia-industry-government relations based on their discussions in a workshop in Abisko, Sweden, in 1994 and subsequent email interactions (Leydesdorff 2018). The original explanation of the concept is captured in their seminal work (Etzkowitz and Leydesdorff 1995), which is largely based on Etzkowitz's observation of the successful collaboration between entrepreneurial universities, such as the Massachusetts Institute of Technology and Stanford University, and high-technology clusters at various stages of development in Boston and Silicon Valley, respectively, mediated by strategic policy interventions (Etzkowitz 1993). Etzkowitz and Leydesdorff (2000) expounded on the Triple Helix as model for studying knowledge-based economies. The central idea is as follows: 'The interaction among university, industry, and government is the key to innovation and growth in a knowledge-based economy' (Etzkowitz 2008: 1). In developing the Triple Helix model, Etzkowitz and Leydesdorff drew insights from multiple disciplines, such as 'evolutionary economics, the sociology of science and technology, and the sociology of higher education, as well as policy analysis with an evaluative perspective' (Zhou 2014: 4).

\section{The Rationale of the Triple Helix Model}

In a recent review and analysis of the theoretical development of the Triple Helix model, Cai and Etzkowitz (2020) summarised the five major aspects of the model. First, the complex relations among various players in regional innovation are simplified according to Simmel's social geometry of triadic interactions. Second, the mechanism of Triple Helix interactions is 'taking the role of the other'. Third, its development is an evolutionary process, but the process needs to be pre-structured or coordinated. Fourth, triple helix interactions require the integration of both topdown coordination and bottom-up initiatives. Finally, the Triple Helix model is enabled by certain tangible and intangible conditions.

\section{Critiques and Recent Developments}

Although the Triple Helix model has gained popularity over the 26 years since it was proposed, it has also been criticised, mainly in relation to the three following factors: First, the theoretical foundations of the model need strengthening (Cooke 2005; Shinn 2002: 609; Viale and Pozzali 2010). Second, the model is not sensitive to contextual environments (Balzat and Hanusch 2004; Cai 2014). Third, new and complex factors that emerge during societal transformations have not been fully considered (Tuunainen 2002; Brundin et al. 2008; Reich-Graefe 2016; Drori et al. 2013). 
Responding to criticisms, particularly that the Triple Helix model is too normative and lacks theoretical foundations, scholars have attempted to improve the model (Cai and Etzkowitz 2020) via two routes. The first approach, underlined by deductive reasoning, augments the theoretical core of the Triple Helix by using insights from other theories. For instance, since the mid-2000s, the two founders of the Triple Helix model, Etzkowitz and Leydesdorff, have further elaborated on the mechanisms of triple helix interactions from a neo-institutional perspective and a neo-evolutionary perspective, respectively (Leydesdorff 2012). The former emphasises the relations between the three spheres of university, industry and government, whereas the latter focusses on the three selection mechanisms-namely, market, innovation and control (Leydesdorff 2021). Moreover, Cai (2015) and Villanueva et al. (2006) have attempted to enhance the theoretical foundations of the Triple Helix from the perspective of institutional logics and social network theory, respectively.

The second approach, driven by inductive reasoning, seeks to further enrich the Triple Helix model via nuanced observations of regional innovations. Some outcomes of this approach are captured in the book Triple Helix: University-industrygovernment innovation in action by Etzkowitz (2008) and its second edition (Etzkowitz and Zhou 2017). Other efforts include the distinction between the Triple Helix core function and the Triple Helix sphere (Zhou 2014) and bring both central and regional governments into the Triple Helix analysis (Cai and Liu 2015; Liu and Cai 2018). Hladchenko and Pinheiro (2019) discovered the phenomenon of 'meansends decoupling' in implementing the Triple Helix model and explained it from the perspective of institutional theory.

\section{Quadruple Helix}

\section{Origin of the Quadruple Helix concept}

While the Triple Helix concept was developed as an intellectual response to the emerging knowledge-based economy in the 1990s, the Quadruple Helix model was proposed to reconceptualise society in the twenty-first century. Carayannis and Campbell (2012), who are considered the founders of the model, wanted 'to develop a more future-oriented outlook and vision, addressing the current challenges and introducing a problem-solving that is interested in sustainable solutions, emphasizing a sustainable development perspective that brings together innovation, entrepreneurship, and democracy' (2). The Quadruple Helix model was originally presented by Carayannis and Campbell (2006) in their book Knowledge creation, diffusion and use in innovation networks and knowledge clusters. It was later consolidated in their article titled "Mode 3" and "Quadruple Helix": Toward a 21st-century fractal innovation ecosystem' (Carayannis and Campbell 2009). Carayannis and Campbell (2009) developed the Quadruple Helix model by adding a fourth helix, defined as 'the media-based and culture-based public and civil society' (Carayannis and Campbell 2012: 13). The fourth helix illustrates that in a modern knowledge society and economy, aside from academia, industry and government, knowledge flows into all spheres of the society and the innovation ecosystem. 
Some other scholars initiated similar efforts to extend the Triple Helix model almost during the same period, but their works were published after those of Carayannis and Campbell (2006, 2009). For instance, at the 8th Triple Helix Conference, Wallin (2010) presented a paper titled The co-evolvement in local development - From the Triple to the Quadruple Helix model. She argued that 'the stakeholders, local employees and inhabitants ... should be disclosed as the fourth helix of the development' because 'without their performance and their active role, the implementation of the high status policy projects might have failed and certainly not gained the outcomes' (Wallin 2010: 6). In an EU-funded research project, Arnkil et al. (2010) proposed the concept of the Quadruple Helix to understand user-driven innovation, and they defined the fourth helix as users. Marcovich and Shinn (2011) proposed the addition of society as the fourth helix in their version of the Quadruple Helix. They referred to society as the 'interactions between groups of people, institutions and knowledge' (Marcovich and Shinn 2011: 177). It is likely that these scholars were not aware of the work by Carayannis and Campbell (2009); at least, they did not cite it in their publications.

\section{The Rationale of the Quadruple Helix Model}

Three aspects constitute the foundation of the Quadruple Helix model. First, democracy or knowledge democracy is an important dimension in understanding the context in which innovation players interact with each other for knowledge production and innovation (Carayannis and Campbell 2017). This corroborates Campbell's (2019) proposition of the global quality of democracy as an innovation enabler. Carayannis and Campbell (2021) further stressed that 'for an innovation system to be a Quadruple/Quintuple Helix innovation system, the political regime hosting these helixes needs to be democratic in essence, not just in form' (1). In a climate of/ for democracy, 'This Quadruple Helix Innovation System Framework puts innovation users at its heart and encourages the development of innovations that are pertinent for users (civil society)' (Carayannis et al. 2018: 150).

Second, the Quadruple Helix model centres on Mode 3 knowledge production, which extends Mode 1 and Mode 2 knowledge production as categorised by Gibbons et al. (1994). Carayannis and Campbell (2012: 4) defined the Mode 3 knowledge production as

the nexus or hub of the emerging twenty-first century Innovation Ecosystem, where people, culture, and technology ... meet and interact to catalyze creativity, trigger invention, and accelerate innovation across scientific and technological disciplines, public and private sectors ... and in a top-down, policydriven as well as bottom-up, entrepreneurship empowered fashion.

They added that 'the competitiveness and superiority' of such a knowledge system 'is highly determined by its adaptive capacity to combine and integrate different knowledge and innovation modes' (Carayannis and Campbell 2009: 221) via 'coexistence, co-evolution, and co-specialization of different knowledge paradigms and different knowledge modes of knowledge production and knowledge use' (Carayannis and Campbell 2012: 4). 
Third, quadruple helix interactions occur in an innovation ecosystem, which is conceptualised by the systems analysis approach (Carayannis and Campbell 2012). As such, the Quadruple Helix framework is viewed as the "enabler and enactor of regional co-opetitive entrepreneurial ecosystems, which we conceptualize as fractal, multi-level, multi-modal, multi-nodal, and multi-lateral configurations of dynamic tangible and intangible assets within the resource-based view and the new theory of the growth of the firm' (Carayannis et al. 2018: 148).

\section{Critiques and Recent Developments}

The first scholarly debate on the Quadruple Helix model was initiated by Leydesdorff and Etzkowitz (2003). In their view, 'conceptualization of the public as merely a fourth helix narrows the public into another private sphere, rather than seeing civil society as the foundation of the enterprise of innovation' (Leydesdorff and Etzkowitz 2003: 57). Leydesdorff (2012) further stressed that perceiving civil society as an additional helix is problematic because it does not have the same characteristics as university, industry and government. In the same vein, Prainsack (2012) criticised the Quadruple Helix model for using existing concepts differently from their original definitions, such as in the model of knowledge production proposed by Gibbons et al. (1994) and the democratisation of science proposed by Funtowicz and Ravetz (1993). Moreover, Leydesdorff et al. (2014) implied that compared with the robust measurement of triple helix interactions to test the validity of the model, the Quadruple Helix model is weak in its methodological basis for quantitative measurement.

Unlike the clear focus of the Triple Helix model on the interactions between university, industry and government, a consistent understanding of what represents the fourth helix is missing. The fourth helix has been variously understood as consumers (Ivanova 2014), users (Arnkil et al. 2010; Miller et al. 2018), non-governmental organisations (Lindberg et al. 2014) and community (Doh 2018). Even in the work of Carayannis and Campbell (2012), the fourth helix has four synonyms-'public', 'media-based and culture-based public', 'arts, artistic research and arts-based innovation' and 'civil society'. As König et al. (2020) noted, 'there is not one Quadruple Helix, but a continuum of models, or at least varieties where different additional spheres become the focus: a "Triple Helix" +1) users model, +2) firm-centered Living Lab model, +3) public sector-centered Living Lab model and +4) citizen-centered model or simply private-public-people partnerships (PPPP)'.

\section{Summary of the Comparison}

Through the comparison, we identified some common theoretical assumptions of both models, which are outlined as follows:

(1) The analysis of knowledge-based developments requires at least three relevant dimensions: university, industry and government. 
(2) Given that both top-down coordination and bottom-up initiatives are crucial to fostering regional innovation, a successful approach is the use of appropriate mechanisms that mediate between them.

(3) Heterogeneous settings are important for innovation. Innovation is best created through the joint actions of players across sectors.

(4) Innovation is associated with co-evolution processes in several domains, such as the socio-economic, political, technological and cultural domains.

(5) Civil society is the most important condition/dimension for innovation.

Nevertheless, the two helix models approach these issues from different theoretical and analytical standpoints, as indicated in the rationales of the models discussed above. Moreover, the two models have different understandings of the helix concept (Table 1).

Table 1 Different understandings of the helix concept by the originators of helix models of innovation

\begin{tabular}{|l|l|l|}
\hline $\begin{array}{l}\text { Originators of } \\
\text { helix models }\end{array}$ & Perspectives & Understandings of helices \\
\hline $\begin{array}{l}\text { Etzkowry } \\
\text { Loet } \\
\text { Leydersdorff }\end{array}$ & Neo-institutional & $\begin{array}{l}\text { The Triple Helix model is composed of the triple helix spheres of } \\
\text { university, industry, government, which are parallel to the triple helix } \\
\text { spaces of knowledge, innovation and consensus (Etzkowitz and Zhou } \\
\text { 2017; Etzkowitz 2008). }\end{array}$ \\
\hline $\begin{array}{l}\text { Elias Carayannis } \\
\text { David } \\
\text { Campbell }\end{array}$ & Eco-systemic & $\begin{array}{l}\text { The Triple Helix is perceived as three functions-namely, wealth } \\
\text { creation, knowledge production, and normative control. The three } \\
\text { helices also operate 'as selection mechanisms asymmetrically on one } \\
\text { another, but mutual selections may shape a trajectory as in a } \\
\text { coevolution' (Leydesdorff 2012: 28). }\end{array}$ \\
\hline $\begin{array}{l}\text { The government, university, industry and civil society represent four } \\
\text { basic dimensions of a Quadruple Helix innovation system (Carayannis } \\
\text { et al. 2018). However, the fourth helix, broadly understood as media- } \\
\text { based and culture-based public or civil society, contextualise the } \\
\text { Triple Helix (Carayannis and Campbell 2021). }\end{array}$ \\
\hline
\end{tabular}

\section{Advantages and Disadvantages of the Triple Helix and Quadruple Helix Models}

This section first presents a comparative lens for the reader to understand our premises of comparison. We synthesise the most relevant literature in the field to describe modern innovation and form a lens that is used to compare the two helix models in the latter part of the section. 


\section{A Comparative Lens: Features of Contemporary Society Related to Innovation}

Both Triple Helix and Quadruple Helix models deal with the mechanism of innovation at the societal level. Thus, when deciding on which model to use in empirical research, one must know about the nature of contemporary society. There are a few concepts, such as knowledge-based society 2.0 (Rutten and Boekema 2012), globalisation 3.0 (Friedman 2005) and innovation ecosystems (Oh et al. 2016), that capture the fundamental changes in society that have occurred since the beginning of the twenty-first century. Of the three, the innovation ecosystem is a more inclusive concept, accentuating the ecological and sustainable aspects of innovation systems (Oh et al. 2016). The innovation ecosystem fosters sustainable innovation (CarrilloHermosilla et al. 2010), defined as 'innovation that improves sustainability performance, where such performance includes ecological, economic, and social criteria' (Boons et al. 2013: 2). Cai et al. (2020) define innovation ecosystems as

co-innovation networks, in which actors from organizations concerned with the functions of knowledge production, wealth creation and norm control interact with each other in forming co-evolution and interdependent relations (both direct or indirect) in cross-geographical contexts, and, through which new ideas and approaches from various internal and external sources are integrated into a platform to generate shared values for the sustainable transformation of the society.

By synthesising relevant literature on innovation ecosystems, knowledge-based society 2.0 and globalisation 3.0, we identify the following three major aspects of contemporary society: (1) the nature of knowledge and mode of knowledge production, (2) the key innovation players and their relations and (3) the temporal and spatial dimensions of social contexts of sustainable innovation. These aspects have also been considered important in innovation studies (Fagerberg et al. 2013). For instance, the first aspect resonates with basis of innovation processes in knowledge, learning and production. We emphasise innovation players and their relations in the second aspect because knowledge- and learning-based innovations are created by multiple players and their interactions. These interactions take place in social contexts; therefore, we also examine context from both the temporal and spatial perspectives as the third aspect. The changes in society in terms of these three aspects are discussed below.

\section{The Nature of Knowledge and Mode of Knowledge Production}

Regarding the nature of knowledge, it has been argued that in knowledge society 2.0, knowledge is not simply categorised as tacit or codified, as it is in knowledgebased society 1.0; instead, it is context dependent (Rutten and Boekema 2012). Further, the model of knowledge production extends from Mode 1 and Mode 2 to Mode 3 (Carayannis and Campbell (2012), in which learning and knowledge production occur in the context of social interactions rather than in organisational contexts e.g. universities or firms (Carayannis and Campbell 2012; Rutten and Boekema 2012). The new features of social interactions for innovation are characterised by 
democratising innovation, as well as hybrid innovation networks and knowledge clusters (Carayannis and Campbell 2012).

\section{Key Innovation Players and Their Relations}

Compared with the innovation processes in innovation systems, in the ecosystem of innovation, there are diverse core factors (e.g. technical, social, environmental), and they are increasingly interdependent (Oh et al. 2016; Smorodinskaya et al. 2017; Walrave et al. 2017; Sotarauta et al. 2016). Cai et al. (2019) argued that some hidden/unobvious relations between players across sectors/nations in innovation ecosystems are important for building trust and co-innovation.

\section{Social Contexts of Sustainable Innovation}

In their study of tensions associated with sustainable development, Hahn et al. (2015) distinguished between temporal and spatial dimensions, which we consider useful for analysing the social context of sustainable innovation. The temporal dimension is underlined by the concept of intergenerational equity, which 'calls for the consideration of the interests of future generations and it is usually assumed that the time horizon of current decision making undervalues the interests of future generations' (Hahn et al. 2015: 307). From a temporal perspective, sustainable innovation must be socially responsible (Flipse 2013); this covers the social and ethical aspects of research, development and innovation, such as environmental development, societal sustainability and social desirability (von Schomberg 2011; Burget et al. 2017). In short, innovation must be responsible for future generations.

The spatial dimension is underlined by the concept of intragenerational equity, which refers to 'equitable development opportunities between developed and underdeveloped regions as well as within both of these' (Hahn et al. 2015: 303). From a spatial perspective, sustainable innovation must be inclusive, enabling 'the process of technological diffusion by which an already developed technology comes to be widely available to poor consumers in developing countries' (Foster and Heeks 2013: 335). The concept of inclusive innovation implies that innovations are often created in developed countries and that the people in developing countries are their recipients or users. However, owing to changes in both the nature of knowledge and the model of knowledge production, innovation is increasingly taking place in global networks that involve developed and developing countries (Barnard and Chaminade 2017). The role of the individual becomes vital in this process (Cai et al. 2019), reflecting the reality described by Friedman (2005) that the cornerstone of globalisation has shifted from countries (globalisation 1.0) and companies (globalisation 2.0) to individuals and groups (globalisation 3.0) . 


\section{Strengths and Weaknesses of the Triple and Quadruple Helix Models vis-à-vis Understanding Contemporary Society}

Using the three main features of contemporary society as a lens, Tables 2 and 3 summarise the strengths and weaknesses of the Triple Helix model and Quadruple Helix model, respectively, in enhancing the understanding of society. These could constitute the basis for deciding which Helix model is most useful in empirical research.

Table 2 Strengths and weaknesses of the Triple Helix model in enhancing understandings of innovation ecosystems

\begin{tabular}{|c|c|c|}
\hline $\begin{array}{l}\text { Changing features in society as a } \\
\text { comparative lens }\end{array}$ & Strengths & Weaknesses \\
\hline $\begin{array}{l}\text { Nature of knowledge and mode } \\
\text { of knowledge production } \\
\text { Knowledge production (Mode } 3 \text { ) } \\
\text { now occurs in the context of social } \\
\text { interactions rather than in } \\
\text { organisational contexts. }\end{array}$ & $\begin{array}{l}\text { The fundamental theoretical } \\
\text { assumption of the Triple Helix } \\
\text { model deals with the creation of } \\
\text { knowledge and innovation in the } \\
\text { context of social interactions. }\end{array}$ & $\begin{array}{l}\text { Some emerging phenomena in } \\
\text { social interactions, such as } \\
\text { democratising innovation, are not } \\
\text { explicit in the theoretical } \\
\text { elaboration of the Triple Helix } \\
\text { model. }\end{array}$ \\
\hline $\begin{array}{l}\text { Key innovation players } \\
\text { Key players in the innovation } \\
\text { process are diverse and } \\
\text { increasingly interdependent, with } \\
\text { unobvious links. }\end{array}$ & $\begin{array}{l}\text { The core mechanisms of the Triple } \\
\text { Helix model are concerned with } \\
\text { relations between primary } \\
\text { innovation actors/sectors. Such a } \\
\text { simple structure makes the model } \\
\text { more operational. }\end{array}$ & $\begin{array}{l}\text { The focus of the Triple Helix } \\
\text { model is on the three primary } \\
\text { actors/sectors, as well as the } \\
\text { relations among them. Although } \\
\text { the model acknowledges the roles } \\
\text { of other actors (as secondary } \\
\text { actors), it does not clarify how } \\
\text { these secondary actors can be } \\
\text { included in Triple Helix analysis. }\end{array}$ \\
\hline $\begin{array}{l}\text { Social contexts of } \begin{array}{r}\text { sustainable } \\
\text { (temporal } \\
\text { innovation } \\
\text { perspective) }\end{array} \\
\text { Social responsibility has become } \\
\text { the norm in innovation activities. }\end{array}$ & $\begin{array}{l}\text { Civic engagement, as the } \\
\text { foundation of socially responsible } \\
\text { innovation, is considered the } \\
\text { institutional ground or 'launch } \\
\text { pad' of the Triple Helix. }\end{array}$ & $\begin{array}{l}\text { Civic engagement, although } \\
\text { regarded as the foundation of the } \\
\text { Triple Helix model, is not } \\
\text { explicitly theorised in the } \\
\text { analytical framework. }\end{array}$ \\
\hline $\begin{array}{l}\text { Social contexts of sustainable } \\
\text { innovation (spatial perspective) } \\
\text { The cornerstone of globalisation } \\
\text { has shifted from countries and } \\
\text { companies to individuals and } \\
\text { groups. }\end{array}$ & $\begin{array}{l}\text { The theoretical core of the Triple } \\
\text { Helix model can potentially } \\
\text { explain emerging issues in the } \\
\text { global context of innovation, as } \\
\text { well as the Triple Helix } \\
\text { interactions at the individual level. }\end{array}$ & $\begin{array}{l}\text { The global dimension and } \\
\text { individual focus are not well } \\
\text { elaborated in the current } \\
\text { theorisation of the Triple Helix } \\
\text { model. }\end{array}$ \\
\hline
\end{tabular}


In short, the advantage of the Triple Helix model is its stronger theoretical foundations on the interactions of university, industry and government, whereas its weakness is that the new features of society concerning innovation have not been explicitly addressed in the theoretical elaboration of the model. The Triple Helix model is firmly rooted in classical sociological theory and institutional economics. Over the past years, the theoretical foundation of the model has been strengthened via multiple disciplinary perspectives, such as the new evolutional theory (Leydesdorff and Meyer 2006), institutional logics (Cai 2015) and social network theory (Villanueva et al. 2006). Even some critics of the Triple Helix model have acknowledged that the model 'represents a critical and sometimes stringent base for further theoretical sociological reflection on innovation dynamics' (Marcovich and Shinn 2011: 176). Meanwhile, Carayannis and Campbell (2009) noted that the origin of

Table 3 Strengths and weaknesses of the Quadruple Helix model in understanding the new features of contemporary society

\begin{tabular}{|c|c|c|}
\hline $\begin{array}{l}\text { Changing features in society as a } \\
\text { comparative lens }\end{array}$ & Strengths & Weaknesses \\
\hline $\begin{array}{l}\text { Nature of knowledge and mode } \\
\text { of knowledge production } \\
\text { Knowledge production (Mode } 3 \text { ) } \\
\text { now occurs in the context of social } \\
\text { interactions rather than in } \\
\text { organisational contexts. }\end{array}$ & $\begin{array}{l}\text { The Mode } 3 \text { knowledge production } \\
\text { system is conceptualised as the } \\
\text { foundation of the Quadruple Helix } \\
\text { model. }\end{array}$ & $\begin{array}{l}\text { The model lacks theoretical } \\
\text { accounts of the mechanism } \\
\text { underlying Mode } 3 \text { knowledge } \\
\text { production. }\end{array}$ \\
\hline $\begin{array}{l}\text { Key innovation players } \\
\text { Key players in the innovation } \\
\text { process are diverse and } \\
\text { increasingly interdependent, with } \\
\text { unobvious links. }\end{array}$ & $\begin{array}{l}\text { The Quadruple Helix model is } \\
\text { flexible enough to include new } \\
\text { factors and actors in the focal } \\
\text { analysis via the fluid construct of } \\
\text { the fourth helix. }\end{array}$ & $\begin{array}{l}\text { Compared with the Triple Helix } \\
\text { model, it is more complex to apply } \\
\text { the Quadruple Helix model to } \\
\text { empirical analysis because more } \\
\text { elements need to be considered. } \\
\text { Particularly, since the Quadruple } \\
\text { Helix model is enabled by a } \\
\text { democratic regime, challenges } \\
\text { emerge when applying the model } \\
\text { to compare innovation processes } \\
\text { between democratic and } \\
\text { authoritarian states. }\end{array}$ \\
\hline $\begin{array}{l}\text { Social contexts of sustainable } \\
\text { innovation (temporal } \\
\text { perspective) } \\
\text { Social responsibility has become } \\
\text { the norm in innovation activities. }\end{array}$ & $\begin{array}{l}\text { Socially responsible innovation is } \\
\text { addressed through the fourth added } \\
\text { helix - the public or civil society } \\
\text { and the concept of democratising } \\
\text { innovation. }\end{array}$ & $\begin{array}{l}\text { Since civil society does not share } \\
\text { the same characteristics as } \\
\text { academia, industry and } \\
\text { government, perceiving it as a } \\
\text { helix parallel to the other three can } \\
\text { be problematic. }\end{array}$ \\
\hline $\begin{array}{l}\text { Social contexts of sustainable } \\
\text { innovation (spatial perspective) } \\
\text { The cornerstone of globalisation } \\
\text { has shifted from countries and } \\
\text { companies to individuals and } \\
\text { groups. }\end{array}$ & $\begin{array}{l}\text { The Quadruple Helix is } \\
\text { conceptualised in the context of } \\
\text { innovation ecosystems, which } \\
\text { embrace the global dimension, as } \\
\text { well as the new trend in } \\
\text { globalisation. }\end{array}$ & $\begin{array}{l}\text { The emerging glocalisation is the } \\
\text { starting point for developing the } \\
\text { Quadruple Helix model, but } \\
\text { relevant issues are elaborated on at } \\
\text { a conceptual level that is not } \\
\text { concrete enough for guiding } \\
\text { empirical analysis. }\end{array}$ \\
\hline
\end{tabular}


the Triple Helix model was mainly based on Modes 1 and 2 of knowledge production. However, the recent theoretical development of the Triple Helix reflects an attempt to explain the dynamics of innovation in contemporary society (Cai and Etzkowitz 2020).

The advantages and disadvantages of the Quadruple Helix are almost the opposite of those of the Triple Helix. Basically, the Quadruple Helix model is more sensitive to the changing nature of society, but it is relatively weak in its theoretical explanatory power and analytical complexity. The fluid construct of the model is both its biggest advantage and its weakness. On the one hand, the model offers conceptual space for the fourth helix, which can be added algorithmically depending on the study's needs (see also Miller et al. 2018; Arnkil et al. 2010); this can stimulate researchers to propose new conceptualisations of the ever-changing social dimension. On the other hand, the new fourth dimension is sometimes difficult to tie down to a solid analytical basis. Nevertheless, efforts have been made to enhance the analytical power of the Quadruple (and Quintuple) Helix model in approaching innovation ecosystems (Carayannis et al. 2016, 2021).

\section{Towards an Ideal Theory of Innovation?}

The comparison discussed above suggests that the Triple Helix model has a relatively strong theoretical foundation, but it still needs to be improved to address the emerging characteristics of contemporary society. In contrast, the Quadruple Helix model has been developed with the specific purpose of addressing phenomena arising from contemporary society, but it is relatively abstract in its theoretical foundation. This raises the following question: Can synergy be built between them to better theorise sustainable innovation in contemporary society?

An ideal theory of innovation can be said to meet the following three criteria: First, the theory can address emerging issues in the innovation process; as Lundvall noted, 'what qualifies as a good theory of innovation is not carved in stone but has to evolve as a result of changes in society and our attempts to understand these challenges' (Fagerberg et al. 2013: 7). Second, the theory must enable effective empirical analysis to avoid being overly complicated in its analytical framework. This is in line with the Occam's razor principle, which advocates including complex constructs only if essential (Braithwaite 2017). Third, the theory should focus on the conditions and mechanisms fostering sustainable innovation, which consists of environmental, social and economic dimensions (Elkington 1998). In Table 4, we illustrate how the Triple Helix and Quadruple Helix models offer useful and supplementing insights through the lens of the three criteria. 
Table 4 Useful insights from the Triple Helix and Quadruple Helix models through the lens of building an ideal innovation theory

\begin{tabular}{|l|l|l|}
\hline Criterion & Insights from Triple Helix & Insights from Quadruple Helix \\
\hline 1 & $\begin{array}{l}\text { University, industry and government, brought } \\
\text { in focus by the Triple Helix model, are also the } \\
\text { main components in (sustainable) innovation } \\
\text { processes in contemporary society. }\end{array}$ & $\begin{array}{l}\text { The model's freely defined fourth helix helps } \\
\text { to include new elements in (sustainable) } \\
\text { innovation processes. }\end{array}$ \\
\hline 3 & $\begin{array}{l}\text { The principle of triadic interactions between } \\
\text { primary helices ensures a simple but feasible } \\
\text { analytical framework. }\end{array}$ & $\begin{array}{l}\text { Civic engagement as emphasised in the model } \\
\text { is an emerging issue in contemporary society in } \\
\text { relation to sustainable innovation. }\end{array}$ \\
$\begin{array}{l}\text { The mechanisms underlying the triple helix } \\
\text { interactions that foster innovation can be } \\
\text { further adapted for strengthening the } \\
\text { theoretical foundations for understanding the } \\
\text { processes of sustainable innovation. }\end{array}$ & $\begin{array}{l}\text { The model was developed with the concept of } \\
\text { an innovation ecosystem; thus, it directly } \\
\text { contributing to the conditions and mechanisms } \\
\text { fostering sustainable innovation. }\end{array}$ \\
\hline
\end{tabular}

It can be seen from the table that the two helix models have opposite emphases and strengths. In other words, they can be supplementary to each other. Thus, integrating the two models has the potential to offer a useful analytical framework to better understand the mechanisms of the innovation process in contemporary society. However, there are challenges to accomplishing this because of the different propensities of the two models. The Quadruple Helix model provides a relatively loose conceptual framework for its flexibility in bringing different elements (e.g. civil society, users, stakeholders) to the fourth helix and its inclination to extend to a quintuple model. This helps include emerging elements in innovation ecosystems into analytical foci. However, for the same reason, the model tends to be too complicated to be operationalised in the empirical analysis. At the same time, the Triple Helix model, with its underlying Occam's razor principle and its focus on the three most essential helices, may limit the inclusion of new factors into the analytical fold of the Triple Helix framework. Thus, the key to synergy building lies in developing an integrated analytical framework that is flexible enough to incorporate emerging factors on the one hand and adheres to the Occam's razor principle on the other.

\section{Conclusions}

Through analysing the state-of-the-art studies using the Triple Helix or Quadruple Helix model, we found a research gap in terms of a lack of studies that systematically compare the two models. For this reason, researchers-especially newcomers to the field - are often confused about which model to apply in their empirical research. To respond to this gap, we compared the Triple Helix and Quadruple Helix models from two perspectives. One focussed on the origins, theorisation and 
criticisms of the two models; the other focussed on the advantages and disadvantages of the two models in terms of addressing innovation issues in contemporary society.

Our study's findings contribute to the scholarly discussions on the Triple Helix and Quadruple Helix in three ways. First, for the first time, we provide a comprehensive comparison of the two models from multiple perspectives. Our literature analysis revealed that when authors choose which model to use, their decisions are driven by several perspectives, which are as follows: (1) The two models are competing concepts, (2) the move from Triple Helix to Quadruple Helix is an evolutionary process, and (3) the two models could be supplementary to each other. The last view is supported by the results of our comparative analysis of the two models: Both Triple Helix and Quadruple Helix share some common theoretical assumptions on innovation; the advantages of one model may make up for the weaknesses of the other.

Second, we discovered some misunderstandings of the helix models in the existing literature. For instance, the primary misperception is that when civil society or other non-traditional triple helices are under observation in research, the Triple Helix model is considered useless or out-of-date. However, according to the originators of the Triple Helix model, the model does not prevent researchers from adding new players/layers around the core helices of universities, industry and government. Particularly, civil society is seen as the social context in which triple helix interactions evolve.

Third, the results of our comparative analysis provide a basis for researchers to choose between the two models to serve their needs in empirical studies. Specifically, we provide the following suggestions: First, each helix model could offer useful insights serving as conceptual or analytical tools for studying various innovation issues in contemporary society, but in doing so, the theoretical rationales of the model must be fully comprehended to avoid superficially applying a concept. Second, since the two models differ in their perspectives on what key innovation players are and how they interact, choosing one over the other depends on specific empirical settings and the main subjects to be investigated, in addition to the researchers' theoretical preferences. Third, researchers are encouraged to advance helix models by building synergies between them, making them supplementary to each other.

As a preliminary effort to compare the Triple Helix and Quadruple Helix models (which has also been constrained by space limitations), our study is limited by the scope of literature to be included in our analysis, as well as our inclusion of other possible comparative lenses. While calling for future research to continuously advance the comparison and dialogue between the two models, we expect to see more studies to build synergy between them. To this end, collaboration between Triple Helix and Quadruple Helix scholars is needed. In the Triple Helix Conference 2020, the Panel 'Triple Helix vs. Quadruple and Quintuple Helix Dialogue' chaired by Yuzhuo Cai as the first author of the article, with Loet Leydesdorff, Elias Carayannis and David Campbell as the panellists, was a good example demonstrating such collaboration (Zheng and Cai 2020). An optimised helix model of innovation (developed through synergy building between the Triple Helix and Quadruple Helix) concerns not only the configurations of helices but also changes within each helix. One example of conceptualisation of the evolution in the university sector, as one of the 


\section{helices, can be seen in Cai and Ahmad's (2021) recent article 'From an Entrepre- neurial University to a Sustainable Entrepreneurial University'.}

Acknowledgements The authors would like to acknowledge the insights and comments of the originators of helix models of innovation, Henry Etzkowitz, Loet Leydesdorff, Elias Carayannis and David Campbell, throughout the process of our writing of the paper. Our thanks are also given to the participants of the Triple Helix Conference 2019 for their questions, remarks and suggestions on an early version of our paper as well as the editor and reviewers of Minerva for their constructive comments.

Funding Not applicable.

\section{Declarations}

Conflict of interest Both authors declare that they have no conflict of interest.

Ethical Approval This article does not contain any studies with human participants performed by any of the authors.

Open Access This article is licensed under a Creative Commons Attribution 4.0 International License, which permits use, sharing, adaptation, distribution and reproduction in any medium or format, as long as you give appropriate credit to the original author(s) and the source, provide a link to the Creative Commons licence, and indicate if changes were made. The images or other third party material in this article are included in the article's Creative Commons licence, unless indicated otherwise in a credit line to the material. If material is not included in the article's Creative Commons licence and your intended use is not permitted by statutory regulation or exceeds the permitted use, you will need to obtain permission directly from the copyright holder. To view a copy of this licence, visit http://creativecommons.org/licen ses/by/4.0\%.

\section{References}

Arnkil, Robert, Anu Järvensivu, Pasi Koski, and Tatu Piirainen. 2010. Exploring Quadruple Helix: Outlining user-oriented innovation models. In Work Research Centre, Working papers 85/2010. Tampere: Institute for Social Research, University of Tampere.

Arranz, Nieves, Marta F. Arroyabe, and Martin Schumann. 2020. The role of NPOs and international actors in the national innovation system: A network-based approach. Technological Forecasting and Social Change 159: 120183. https://doi.org/10.1016/j.techfore.2020.120183.

Balzat, Markus, and Horst Hanusch. 2004. Recent trends in the research on national innovation systems. Journal of Evolutionary Economics 14(2): 197-210.

Barnard, Helena, and Cristina Chaminade. 2017. Openness of innovation systems through global innovation networks: a comparative analysis of firms in developed and emerging economies. International Journal of Technological Learning, Innovation and Development 9(3): 269-292. https://doi.org/10. 1504/IJTLID.2017.10008256.

Boons, Frank, Carlos Montalvo, Jaco Quist, and Marcus Wagner. 2013. Sustainable innovation, business models and economic performance: an overview. Journal of Cleaner Production 45: 1-8. https:// doi.org/10.1016/j.jclepro.2012.08.013.

Braithwaite, Jason J. 2017. Occam's Razor: The Principle of Parsimony. Academia.edu. https://www. academia.edu/1742741/Occams_Razor_The_principle_of_Parsimony. Accessed 14 Aug 2019.

Brundin, Ethel, Caroline Wigren, Eslyn Isaacs, Chris Friedrich, and Kobus Visser. 2008. Triple Helix Networks in a multiculral context: Triggers and barrirs for fostering growth and sustainability. Journal of Developmental Entrepreneurship 13(1): 77-98. 
Burget, Mirjam, Emanuele Bardone, and Margus Pedaste. 2017. Definitions and Conceptual Dimensions of Responsible Research and Innovation: A Literature Review. Science and Engineering Ethics 23(1): 1-19. https://doi.org/10.1007/s11948-016-9782-1.

Cai, Yuzhuo. 2014. Implementing the Triple Helix model in a non-Western context: an institutional logics perspective. Triple Helix 1(1): 1-20. https://doi.org/10.1186/s40604-014-0001-2.

Cai, Yuzhuo. 2015. What contextual factors shape "innovation in innovation"?-Integration of insights of the Triple Helix and the institutional logics perspective. Social Science Information 54(3): 299-326. https://doi.org/10.1177/0539018415583527.

Cai, Yuzhuo. 2020. 'Innovation in Innovation': A Review of Henry Etzkowitz and Chunyan Zhou, The Triple Helix: University-Industry-Government Innovation and Entrepreneurship (Second Edition). Minerva 58(4): 651-656. https://doi.org/10.1007/s11024-020-09418-1.

Cai, Yuzhuo, and Ijaz Ahmad. 2021. From an Entrepreneurial University to a Sustainable Entrepreneurial University: Conceptualization and Evidence in the Contexts of European University Reforms. Higher Education Policy. https://doi.org/10.1057/s41307-021-00243-z.

Cai, Yuzhuo, and Henry Etzkowitz. 2020. Theorizing the Triple Helix model: Past, present, and future. Triple Helix 7(2-3): 189-226. https://doi.org/10.1163/21971927-bja10003.

Cai, Yuzhuo, Borja Ramis Ferrer, and Jose Luis Martinez Lastra. 2019. Building University-Industry Co-Innovation Networks in Transnational Innovation Ecosystems: Towards a Transdisciplinary Approach of Integrating Social Sciences and Artificial Intelligence. Sustainability 11(17): 1-23. https://doi.org/10.3390/su11174633.

Cai, Yuzhuo, and Cui Liu. 2015. The roles of universities in fostering knowledge-intensive clusters in Chinese regional innovation systems. Science and Public Policy 42(1): 15-29. https://doi.org/10. 1093/scipol/scu018.

Cai, Yuzhuo, Jinyuan Ma, and Qiongqiong Chen. 2020. Higher Education in Innovation Ecosystems. Sustainability 12(11): 4376. https://doi.org/10.3390/su12114376.

Campbell, David F. J. 2019. Global Quality of Democracy as Innovation Enabler: Measuring Democracy for Success. Cham: Palgrave Macmillan. https://doi.org/10.1007/978-3-319-72529-1.

Carayannis, Elias G., and D.F.J. Campbell. 2006. Knowledge Creation, Diffusion, and Use in Innovation Networks and Knowledge Clusters: A Comparative Systems Approach Across the United States, Europe, and Asia. Westport: Praeger Publishers.

Carayannis, Elias G., and David F. J. Campbell. 2009. "Mode 3" and "Quadruple helix": toward a 21st century fractal innovation ecosystem. International Journal of Technology Management 46(3/4): 201-234.

Carayannis, Elias G., and David F. J. Campbell. 2012. Mode 3 Knowledge Production in Quadruple Helix Innovation Systems. SpringerBriefs in Business 7. New York: Springer.

Carayannis, Elias G., and David F. J. Campbell. 2017. Quadruple and Quintuple Helix Innovation Systems and Mode 3 Knowledge Production. In Handbook of Cyber-Development, Cyber-Democracy, and Cyber-Defense, eds. Elias G. Carayannis, David F. J. Campbell, and Marios Panagiotis Efthymiopoulos, 1-19. Cham: Springer.

Carayannis, Elias G., and David F. J. Campbell. 2021. Democracy of Climate and Climate for Democracy: the Evolution of Quadruple and Quintuple Helix Innovation Systems. Journal of the Knowledge Economy. https://doi.org/10.1007/s13132-021-00778-x.

Carayannis, Elias G., and David F.J. Campbell. 2010. Triple Helix, Quadruple Helix and Quintuple Helix and how do knowledge, innovation, and environment relate to each other? International Journal of Social Ecology and Sustainable Development 1: 41-69.

Carayannis, Elias G., and David F.J. Campbell. 2013. Mode 3 Knowledge Production in Quadruple Helix Innovation Systems: 21st-Century Democracy, Innovation, and Entrepreneurship for Development. SpringerBriefs in Business. https://doi.org/10.1007/978-1-4614-2062-0.

Carayannis, Elias G., Evangelos Grigoroudis, David F. J. Campbell, Dirk Meissner, and Dimitra Stamati. 2018. The ecosystem as helix: an exploratory theory-building study of regional co-opetitive entrepreneurial ecosystems as Quadruple/Quintuple Helix Innovation Models. R\&D Management 48(1): 148-162. https://doi.org/10.1111/radm.12300.

Carayannis, Elias G., Evangelos Grigoroudis, and Yorgos Goletsis. 2016. A multilevel and multistage efficiency evaluation of innovation systems: A multiobjective DEA approach. Expert Systems with Applications 62: 63-80. https://doi.org/10.1016/j.eswa.2016.06.017.

Carayannis, Elias G., Evangelos Grigoroudis, Dimitra Stamati, and Theodora Valvi. 2021. Social Business Model Innovation: A Quadruple/Quintuple Helix-Based Social Innovation Ecosystem. Ieee 
Transactions on Engineering Management 68(1): 235-248. https://doi.org/10.1109/tem.2019.29144 08.

Carrillo-Hermosilla, Javier, Pablo del Río, and Totti Könnölä. 2010. Diversity of eco-innovations: Reflections from selected case studies. Journal of Cleaner Production 18(10): 1073-1083. https://doi.org/ 10.1016/j.jclepro.2010.02.014.

Cooke, Phil. 2005. Regionally asymmetric knowledge capabilities and open innovation: Exploring 'Globalisation 2'-A new model of industry organisation. Research Policy 34(8): 1128-1149. https:// doi.org/10.1016/j.respol.2004.12.005.

De Oliveira Monteiro, S.P., and Elias G. Carayannis. 2017. The Quadruple Innovation Helix Nexus: A Smart Growth Model, Quantitative Empirical Validation and Operationalization for OECD Countries. New York: Palgrave Macmillan.

Doh, Pascal. 2018. A Quadruple Helix Framework for University-led Community Innovation Systems in Africa. In Theoretical and Methodological Perspectives of Higher Education Management and Transformation: an advanced reader for PhD students, eds. Elias Pekkola, Jussi Kivisto, Vuokko Kohtamäki, Yuzhuo Cai, and Anu Lyytinen, 87-104. Tampere: Tampere University Press.

Drori, Gili S., Ohad Barkai, Amy Ben-Dor, Navah Berger, Alexandr Bucevschi, Noga Caspi, Avida Netivi, and Henry Etzkowitz. 2013. The Helix Model of Innovation in Israel: The Institutional and Relational Landscape of Israel's Innovation Economy. Jerusalem: The Hebrew University off Jerusalem.

Elkington, John. 1998. Partnerships from cannibals with forks: The triple bottom line of 21st-century business. Environmental Quality Management 8(1): 37-51. https://doi.org/10.1002/tqem.33100 80106.

Etzkowitz, Henry. 1993. Technology transfer: the second academic revolution. Technology Access Report 6(7-9): 1-19.

Etzkowitz, Henry. 1994. Academic-Industry Relations: A Sociological Paradigm for Economic Development. In Evolutionary Economics and Chaos Theory: New Directions for Technology Studies, eds. L. Leydesdorff and P. Van den Besselaar, 139-151. London: Palgrave.

Etzkowitz, Henry. 2008. The triple helix: university-industry-government innovation in action. New York: Routledge.

Etzkowitz, Henry. 2014. Making a humanities town: knowledge-infused clusters, civic entrepreneurship and civil society in local innovation systems. Triple Helix 1(1): 1. https://doi.org/10.1186/ s40604-014-0012-z.

Etzkowitz, Henry, and Loet Leydesdorff. 1995. The Triple Helix-University-Industry-Government Relations: A Laboratory for Knowledge-Based Economic Development. EASST Review 14: 14-19.

Etzkowitz, Henry, and Loet Leydesdorff. 2000. The dynamics of innovation: from National Systems and "Mode 2" to a Triple Helix of university-industry-government relations. Research Policy 29(2): 109-123. https://doi.org/10.1016/S0048-7333(99)00055-4.

Etzkowitz, Henry, and Chunyan Zhou. 2006. Triple Helix twins: innovation and sustainability. Science and Public Policy 33(1): 77-83.

Etzkowitz, Henry, and Chunyan Zhou. 2017. The Triple Helix: University-Industry-Government Innovation and Entrepreneurship, 2nd ed. Abingdon: Routledge.

Fagerberg, Jan, Ben R. Martin, and Esben Sloth Andersen. 2013. Innovation studies: evolution and future challenges. Oxford: Oxford University Press.

Farinha, Luís, João Ferreira, and Borges Gouveia. 2016. Networks of Innovation and Competitiveness: A Triple Helix Case Study. Journal of the Knowledge Economy 7(1): 259-275. https://doi.org/10. 1007/s13132-014-0218-3.

Flipse, Steven M. 2013. Enhancing Socially Responsible Innovation in Industry. Delft: Delft University of Technology.

Foster, Christopher, and Richard Heeks. 2013. Conceptualising Inclusive Innovation: Modifying Systems of Innovation Frameworks to Understand Diffusion of New Technology to Low-Income Consumers. The European Journal of Development Research 25(3): 333-355. https://doi.org/10.1057/ejdr. 2013.7.

Friedman, Thomas L. 2005. The world is flat: a brief history of the globalized world in the twenty-first century. London: Allen Lane.

Funtowicz, Silvio O., and Jerome R. Ravetz. 1993. Science for the post-normal age. Futures 25(7): 739755. https://doi.org/10.1016/0016-3287(93)90022-L. 
Gibbons, Michael, Camille Limoges, Helga Nowotny, Simon Schwartzman, Peter Scott, and Martin Trow. 1994. The new production of knowledge. The dynamics of science and research in contemporary societies. London: Sage.

Hahn, Tobias, Jonatan Pinkse, Lutz Preuss, and Frank Figge. 2015. Tensions in Corporate Sustainability: Towards an Integrative Framework. Journal of Business Ethics 127(2): 297-316. https://doi.org/10. 1007/s10551-014-2047-5.

Hladchenko, Myroslava, and Romulo Pinheiro. 2019. Implementing the Triple Helix Model: Means-Ends Decoupling at the State Level? Minerva 57(1): 1-22. https://doi.org/10.1007/s11024-018-9355-3.

Ivanova, Inga. 2014. Quadruple Helix Systems and Symmetry: a Step Towards Helix Innovation System Classification. Journal of the Knowledge Economy 5(2): 357-369. https://doi.org/10.1007/ s13132-014-0201-z.

König, Jonas, Lech Suwala, and Colin Delargy. 2020. Helix Models of Innovation and Sustainable Development Goals. In Industry, Innovation and Infrastructure, eds. Walter Leal Filho, Anabela Marisa Azul, Luciana Brandli, Amanda Lange Salvia, and Tony Wall, 1-15. Cham: Springer.

Leydesdorff, Loet. 1994. New Models of Technological Change: New Theories for Technology Studies (Epilogue). In Evolutionary Economics and Chaos Theory: New Directions for Technology Studies, eds. L. Leydesdorff and P. Van den Besselaar, 180-192. London: Palgrave.

Leydesdorff, Loet. 2012. The Triple Helix, Quadruple Helix, ..., and an <i $>\mathrm{N}$-Tuple of Helices: Explanatory Models for Analyzing the Knowledge-Based Economy? Journal of the Knowledge Economy 3(1): 25-35. https://doi.org/10.1007/s13132-011-0049-4.

Leydesdorff, Loet. 2018. Synergy in Knowledge-Based Innovation Systems at National and Regional Levels: The Triple-Helix Model and the Fourth Industrial Revolution. Journal of Open Innovation: Technology, Market, and Complexity 4(2): 1-13.

Leydesdorff, Loet. 2021. The Evolutionary Dynamics of Discursive Knowledge: Communication-Theoretical Perspectives on an Empirical Philosophy of Science. Cham: Springer.

Leydesdorff, Loet, and Henry Etzkowitz. 2003. Can "The Public" Be Considered as a Fourth Helix in University-Industry-Government Relations? Report of the Fourth Triple Helix Conference. Science \& Public Policy 30(1): 55-61.

Leydesdorff, Loet, and Martin Meyer. 2006. Triple Helix indicators of knowledge-based innovation systems: Introduction to the special issue. Research Policy 35(10): 1441-1449. https://doi.org/10. 1016/j.respol.2006.09.016.

Leydesdorff, Loet, Han Woo Park, and Balazs Lengyel. 2014. A routine for measuring synergy in university-industry-government relations: mutual information as a Triple-Helix and Quadruple-Helix indicator. Scientometrics 99(1): 27-35. https://doi.org/10.1007/s11192-013-1079-4.

Leydesdorff, Loet, and Helen Lawton Smith. 2021. Triple, Quadruple, and Higher-Order Helices: Historical Phenomena and (Neo-)Evolutionary Models. Triple Helix (Advance access).

Lindberg, Malin, Monica Lindgren, and Johann Packendorff. 2014. Quadruple Helix as a Way to Bridge the Gender Gap in Entrepreneurship: The Case of an Innovation System Project in the Baltic Sea Region. Journal of the Knowledge Economy 5(1): 94-113. https://doi.org/10.1007/ s13132-012-0098-3.

Liu, Cui, and Yuzhuo Cai. 2018. Triple Helix Model and Institutional Logics in Shenzhen Special Economic Zone. Science and Public Policy 45(2): 221-231. https://doi.org/10.1093/scipol/scx059.

Marcovich, Anne, and Terry Shinn. 2011. From the Triple Helix to a Quadruple Helix? The Case of DipPen Nanolithography. Minerva 49(2): 175-190. https://doi.org/10.1007/s11024-011-9169-z.

Marques, Carla, Ana Vanessa Marques, Vitor Braga, and Vanessa Ratten. 2020. Technological transfer and spillovers within the RIS3 entrepreneurial ecosystems: a quadruple helix approach. Knowledge Management Research \& Practice. https://doi.org/10.1080/14778238.2020.1777909.

McAdam, Maura, and Koenraad Debackere. 2018. Beyond 'triple helix' toward 'quadruple helix' models in regional innovation systems: implications for theory and practice. R\&D Management 48(1): 3-6. https://doi.org/10.1111/radm.12309.

Miller, Kristel, Rodney McAdam, and Maura McAdam. 2018. A systematic literature review of university technology transfer from a quadruple helix perspective: toward a research agenda. $R \& D$ Management 48(1): 7-24. https://doi.org/10.1111/radm.12228.

Miron, Dumitru, and Ioan Alexandru Gherasim. 2018. Linking the triple helix (university-industry-government) to the quadruple helix of university-industry-government - civil society in the field of international business and economics. 12(1):612. https://doi.org/10.2478/picbe-2018-0055. 
Mok, Ka Ho., and Jin Jiang. 2020. Towards corporatized collaborative governance: the multiple networks model and entrepreneurial universities in Hong Kong. Studies in Higher Education 45(10): 21102120. https://doi.org/10.1080/03075079.2020.1823647.

Nordberg, Kenneth, Åge. Mariussen, and Seija Virkkala. 2020. Community-driven social innovation and quadruple helix coordination in rural development. Case study on LEADER group Aktion Österbotten. Journal of Rural Studies 79: 157-168. https://doi.org/10.1016/j.jrurstud.2020.08.001.

Oh, Deog-Seong, Fred Phillips, Sehee Park, and Eunghyun Lee. 2016. Innovation ecosystems: A critical examination. Technovation 54(Supplement C): 1-6. https://doi.org/10.1016/j.technovation.2016.02. 004.

Porto-Gomez, Igone, Jon Mikel Zabala-Iturriagagoitia, and Loet Leydesdorff. 2019. Innovation systems in México: A matter of missing synergies. Technological Forecasting and Social Change 148: 119721. https://doi.org/10.1016/j.techfore.2019.119721.

Prainsack, Barbara. 2012. Elias G. Carayannis and David F. J. Campbell, Mode 3 Knowledge Production in Quadruple Helix Innovation Systems: 21st-Century Democracy, Innovation, and Entrepreneurship for Development. Minerva 50(1): 139-142. https://doi.org/10.1007/s11024-012-9194-6.

Reich-Graefe, René. 2016. Intermediation in intermediation: triple helix innovation and intermediary legal organisation. 3(1):1. https://doi.org/10.1186/s40604-016-0041-x.

Rutten, Roel, and Frans Boekema. 2012. From Learning Region to Learning in a Socio-spatial Context. Regional Studies 46(8): 981-992. https://doi.org/10.1080/00343404.2012.712679.

Saviano, M., S. Barile, F. Farioli, and F. Orecchini. 2019. Strengthening the science-policy-industry interface for progressing toward sustainability: a systems thinking view. Sustainability Science 14(6): 1549-1564. https://doi.org/10.1007/s11625-019-00668-x.

Shinn, Terry. 2002. The Triple Helix and New Production of Knowledge: Prepackaged Thinking on Science and Technology. Social Studies of Science 32(4): 599-614.

Smorodinskaya, Nataliya, Martha G. Russell, Daniel Katukov, and Kaisa Still. 2017. Innovation Ecosystems vs. Innovation Systems in Terms of Collaboration and Co-creation of Value. In The 50th Hawaii International Conference on System Sciences. Waikoloa, Hawaii.

Sotarauta, Markku, Tuomo Heinonen, Pasi Sorvisto, and Jari Kolehmainen. 2016. Innovation ecosystems, competences and leadership: Human spare parts and venture finance ecosystems under scrutiny. Helsinki: Tekes - the Finnish Funding Agency for Innovation

Tuunainen, Juha. 2002. Reconsidering the Mode 2 and the Triple Helix: A Critical Comment Based on a Case Study. Science Studies 15(2): 36-58.

Viale, Riccardo, and Andrea Pozzali. 2010. Complex Adaptive Systems and the Evolutionary Triple Helix. Critical Sociology 36(4): 575-594. https://doi.org/10.1177/0896920510365923.

Villanueva, Africa, Jordi Molas-Gallart, and Alejandro Escriba Esteve. 2006. Measuring Triple Helix Linkages: A Contribution from Embeddedness Theory. In Paper presented at the The 6th Biennial International Conference on University, Industry and Government Linkages, Singapore, 16-18 May

von Schomberg, René. 2011. Prospects for technology assessment in a framework of responsible research and innovation. In Technikfolgen abschätzen lehren. Bildungspotenziale transdisziplinärer Methoden, eds. M. Dusseldorp and R. Beecroft, 39-61. Dordrecht: Springer.

Wallin, Sirkku. 2010. The co-evolvement in local development-From the triple to the quadruple helix model. In VIII Triple Helix Conference. Madrid.

Walrave, Bob, Madis Talmar, Ksenia S. Podoynitsyna, A. Georges, L. Romme, and Geert P. J. Verbong. 2017. A multi-level perspective on innovation ecosystems for path-breaking innovation. Technological Forecasting and Social Change. https://doi.org/10.1016/j.techfore.2017.04.011.

Zheng, Gaoming, and Yuzhuo Cai. 2020. Conference Day 1: Triple Helix vs. Quadruple and Quintuple Helix Dialogue. https://events.tuni.fi/thc2020/updates-from-the-conference-sessions/conferenceday-1-triple-helix-vs-quadruple-and-quintuple-helix-dialogue/. Accessed 2 Aug 2021.

Zheng, Peijun. 2010. The "Second Academic Revolution": Interpretations of Academic Entrepreneurship. Canadian Journal of Higher Education 40(2): 35-50.

Zhou, Chunyan. 2014. Four dimensions to observe a Triple Helix: invention of 'cored model' and differentiation of institutional and functional spheres. Triple Helix 1(1): 1-20. https://doi.org/10.1186/ s40604-014-0011-0.

Publisher's Note Springer Nature remains neutral with regard to jurisdictional claims in published maps and institutional affiliations. 